\title{
ANALYSIS OF THE RISK MANAGEMENT PRACTICE IN THE SERBIAN COMPANIES
}

\author{
Lidija Barjaktarović, \\ Kosana Vićentijević
}

Singidunum University,

Belgrade, Serbia

\begin{abstract}
:
The subject of this research is to determine the level of risk management within companies which perform businesses in the Republic of Serbia. The aim of the study is to underline the importance of international practice and standards in implementing risk management process in the daily business of legal entities. On the basis of sample of 154 companies which perform business in the Republic of Serbia in 2015 (as extension of executed research in the period from 2012 to 2014 on the sample of 4,084 ) it is confirmed that harmonization of regulation in the risk management and international financial reporting contributes to improvement of reporting on risk management in Serbian companies. Differences in the level of development and reporting on risk management, are determined by regulation in particular industries; education, competence and experience of employees; ownership structure and applied information technologies. The future researches will go in direction of ascertaining the connection between reporting on risk management and the business performances of entities in real and insurance sectors.
\end{abstract}

Keywords:

risk management, regulation, banks, insurance companies, top companies.

\section{INTRODUCTION}

In broader sense, risk management is the art of making decisions in unpredictable circumstances. Risk management implies optimization of risk management costs and compliance with a business philosophy, culture and climate of the organization. It is a central part of strategic management and corporate governance of any legal entity. ${ }^{1}$ Identification and mitigation of risks are in the focus of good risk management. The aims of risk management within the company are: 1) the company can survive losses and maintains further growth afterwards, 2) efficient performance in a risky environment, and 3) permanent compliance with regulations. Accordingly, risk management is a dynamic, continual and permanent developing process which is spreading through implemented organizational strategy. ${ }^{2}$

ERM (Enterprise Risk Management) is the concept initiated by COSO (The Committee of Sponsoring Organizations), and it is defined as a process (initiated by supervisory board, management and other employees) which represents an integral part of a company's strategy, aimed at identifying potential events which will have an impact on business, in order to improve risk management within an existing level of a particular risk acceptance. It is a discipline of evaluation, control, financing and monitoring of all risks within the company in order to increase the value for its shareholders. ${ }^{3}$ Accordingly, all risks are considered at the same time within a coordinated and strategic frame. ${ }^{4}$ The main hypothesis of the research is that harmonization of regulation in risk management and international financial reporting contributes to the improvement of reporting on risk management in Serbian companies.

1 Vaughan, E., Vaughan, T. (1995) Osnovi osiguranja - Upravljanje rizicima, MATE, Zagreb

2 Barjaktarović L. (2013) Upravljanje rizikom, Univerzitet Singidunum, Beograd

3 COSO (2004) Enterprise Risk management-Integrated Framework 
Having in mind the defined subject, aim and hypothesis, the research consists of five chapters including introduction and conclusion. The second chapter represents relevant literature review for the research. Within the third part the methodology is presented. The results of the research are presented in the fourth chapter. The conclusion is presented within the last chapter.

\section{LITERATURE REVIEW}

CBOK's research (2015) confirmed that risk management is being permanently developed on the global level, and recession contributed to the improvement of the regulation. Accordingly, Europe shows a higher level of the formal established process of risk management compared to the other world regions. Furthermore, it is indicative that the financial sector has the dominant role in that sense on the global level. ${ }^{5}$ Jelenković and Barjaktarović $(2016)^{6}$ confirmed that institutional approach drives to the establishment of the risk management function in legal entities (in case of banks and insurance companies). The research included: 1) a sample of 4,084 Serbian companies which performed business on $12 / 31 / 14$, i.e. 30 banks (total banking sector), 25 insurance companies (total insurance sector) and 4,029 companies in the real sector (including 7 companies whose shares are subject of trade on the Belgrade Stock Exchange) which represented $80 \%$ of the total number of companies which perform business in the country, according to turn-over in 2014 (Law on legal entities, 2015). ${ }^{7}$ 2) The period of analysis 20123Q2015, on the basis of official reports of those companies announced on sites of the Business Registers Agency (BRA), National bank of Serbia (NBS) and the analysed companies. The research that was conducted clearly pointed out that the banking sector had a leading role in the risk management practice and treasury functions. Furthermore, the insurance sector is lagging behind the banking sector in terms of both functions. Finally, the real sector is far behind those two groups of legal entities in terms of risk management and treasury function.

Barjaktarović et al. (2017) did an inquiry among Serbian CFOs (Chief Financial Officer) in the real sector in 2015. It confirmed that: 1) Serbian companies were prone to the traditional risk management approach, 2) ownership structure and the size of a company had an influence on the familiarity with ERM and its appliance, 3) there weren't well-developed

4 Beasley M, Pagach D, Warr R. (2008), Information conveyed in hiring announcements of senior executives overseeing enterprise - wide risk management processes, Journal of Accounting, Auditing and Finance, pp. 23: 311-332

5 Radoš, B. (2016) Upravljanje rizicima - trendovi i prakse, zbornik radova FINIZ 2016 - Rizici u savremenim uslovima poslovanja. str. 82-87

6 Jelenković, Z., Barjaktarović L. (2016) The Risk Management Functions in the Conditions of Globalization: Case Study of the Republic of Serbia. Management 2016/79, pp. 37-45

7 Law on Legal Entities (2015) Official Gazette of the Republic of Serbia No. 36/2011, 99/2011, 83/2014 - other laws and 5/2015 organizational structures and internal control systems which would contribute to the better implementation of ERM. The general conclusion was that ERM wasn't developed within Serbian companies in the real sector. ${ }^{8}$ Finally, Barjaktarović et al. (2014) confirmed that there was a connection between the ERM concept and an increase of a company's value for shareholders. ${ }^{9}$

\section{METHODOLOGY}

This research represents an expansion of a research done by Jelenković and Barjaktarović $(2016)^{10}$, for the whole of 2015 , connected to the risk management reporting of the Serbian companies. The sample consists of 154 legal entities, out of which 30 are banks (total banking sector), 24 insurance companies (total insurance sector) and top $100 \mathrm{com}$ panies in the real sector according to the achieved income and profit in the period from 2008 to 2015 . The sources for research are different official business reports of the analysed Serbian companies (individually and totally), available on sites of BRA, NBS and Business Info Group publication on top 100 companies. ${ }^{11}$ Those sites were accessed in the period from $03 / 28 / 17$ to $04 / 19 / 17$.

The current Serbian regulation is the basis for the conducted research, in terms of risk management frame and reporting on it. Accordingly, the supervisory board or management board (depending on the legal form of the company) is responsible for the establishment of the accounting policy and risk management within the company. ${ }^{12}$ Furthermore, companies in the real sector report on risk management according to International Financial Reporting Standards (IFRS) $7 \cdot{ }^{13}$ In the financial sector - banking and insurance, the relevant risk management regulation is connected to the prime activity based on the European regulation (in compliance with Basel II and Basel III for banking sector; and Solvency II for the insurance sector). ${ }^{14}$

\section{THE RESULTS OF THE RESEARCH}

The risk management process and reporting of the legal entity are in a continuous improvement annually. In all sectors, mergers and acquisitions are present, which consequently

8 Barjaktarović, L., Pindžo, R., Đulić K., Vjetrov, A. (2017) Analiza primene ERM koncepta u Srbiji: uporedna analiza finansijskog i realnog sektora, Bankarstvo - at the publication stage

9 Barjaktarović, L., Vićentijević, K., Vjetrov, A. (2014) Analiza upravljanja rizicima na primeru kompanije Henkel, zbornik radova FINIZ 2014- Finansijsko izveštavanje u funkciji korporativnog upravljanja, str. 15

10 Jelenković, Z., Barjaktarović L. (2016) The Risk Management Functions in the Conditions of Globalization: Case Study of the Republic of Serbia. Management 2016/79, pp. 37-45

11 Business Info Group (2016) 100 najvećih 100 najboljih

12 Law on Legal Entities (2015) Official Gazette of the Republic of Serbia No. 36/2011, 99/2011, 83/2014 - other laws and 5/2015

13 International Financial Reporting Standards (IFRS), http://www. mfin.gov.rs/pages/article.php?id=10266 
leadto changes in practice and the reporting of risk management. Table 1 specifies the risk management practice in the Serbian companies, i.e. that regulation is the basis for it, but the differences in the quality of announced information are a result of variation in the level of the risk management development within the company, and by the competence of people in charge. Thereby, it is important to emphasize that any regulation gives frame for the risk management, but the implementation is up to the company i.e. to do it in accordance with one's own risk appetite. The performed research determined that: 1) domestic companies in foreign ownership are better at the risk management practice compared to those in a domestic ownership; regarding the domestic ownership, a further differentiation is made between those in private and state ownership. 2) Banks have the best risk management practices ${ }^{15}$, and after them follow the insurance companies ${ }^{16}$ (according to the announced reports). Furthermore, $\mathrm{NBS}^{17}$ emphasizes that this established cooperation with Austrian, Slovenian and Italian supervisory. Finally, it implies that domestic legal entities in foreign ownership have established a better risk management practice.

Table 1. Comparative overview of the risk management frame in the Republic of Serbia

\begin{tabular}{|c|c|c|c|c|}
\hline $\begin{array}{l}\text { Company / } \\
\text { Category }\end{array}$ & Risks & System & $\begin{array}{l}\text { Quality of Information } \\
\text { (Better or Different) }\end{array}$ & Note \\
\hline Banks & $\begin{array}{l}\text { Defined by the Law on } \\
\text { the basis of Basel Rules } \\
\text { II and III ( } 10 \text { basic risks) }\end{array}$ & $\begin{array}{l}\text { Defined by the law (dif- } \\
\text { ferent bodies, depart- } \\
\text { ments, committees, } \\
\text { responsible persons) }\end{array}$ & $\begin{array}{l}\text { Erste, UniCredit, Intesa, } \\
\text { Credit Agricole, ProCred- } \\
\text { it, NBG Vojvodjanska } \\
\text { bank }\end{array}$ & $\begin{array}{l}\text { The level of risk man- } \\
\text { agement development } \\
\text { is based on a different } \\
\text { ownership (foreign } \\
\text { owned banks have a } \\
\text { better risk management } \\
\text { practice) }\end{array}$ \\
\hline $\begin{array}{l}\text { Insurance } \\
\text { companies }\end{array}$ & $\begin{array}{l}\text { Defined by the Law } \\
\text { based on Solvency II ( } 8 \\
\text { basic risks) }\end{array}$ & $\begin{array}{l}\text { Defined by the law } \\
\text { (where the main re- } \\
\text { sponsibility is on the } \\
\text { general manager and } \\
\text { supervisory board of the } \\
\text { company) }\end{array}$ & $\begin{array}{l}\text { Generali, Grawe, AXA } \\
\text { life, Dunav, Merkur, Soci- } \\
\text { ete Generale, Energopro- } \\
\text { jekt Garant }\end{array}$ & $\begin{array}{l}\text { The level of risk man- } \\
\text { agement development } \\
\text { is based on a different } \\
\text { ownership (foreign } \\
\text { owned banks have bet- } \\
\text { ter risk management } \\
\text { practice) }\end{array}$ \\
\hline Real sector & $\begin{array}{l}\text { Defined by the Law } \\
\text { based on IFRS } 7 \text { ( } 4 \text { basic } \\
\text { risks) }\end{array}$ & $\begin{array}{l}\text { Management of the } \\
\text { company (financial de- } \\
\text { partment can exception- } \\
\text { ally be responsible for } \\
\text { financial risks i.e. owners } \\
\text { of the company for the } \\
\text { capital risk manage- } \\
\text { ment) }\end{array}$ & $\begin{array}{l}\text { Philip Morris, Lafarge, } \\
\text { Mozzart }\end{array}$ & $\begin{array}{l}\text { The level of risk man- } \\
\text { agement development } \\
\text { is based on a different } \\
\text { ownership structure } \\
\text { (domestic - private and } \\
\text { state owned, and foreign; } \\
\text { and group of connected } \\
\text { companies in the coun- } \\
\text { try and abroad) }\end{array}$ \\
\hline
\end{tabular}

Source: authors prepared this on the basis of the data available on the sites of NBS, BRA and Ministry of Finance of the Republic of Serbia

14 Law on Banks (2015) Official Gazette of the Republic of Serbia No. $107 / 2005$, 91/2010, 14/2015; Law on NBS (2015) RS 72/2003, 55/2004, 85/2005, 44/2010, 76/2012, 106/2012, 14/2015, 40/2015; Law on Insurance (2014) Official Gazette of the Republic of Serbia No. 55/2004, 70/2004, 61/2005,85/2005, 101/2007, 63/2009, 107/2009, 99/2011, 119/2012, 116/2013 and 139/2014; Decision on Publishing Banks' Information and Data (2015) Official Gazette of the Republic of Serbia No. 4/2015; Decision on Management System in Insurance and Reinsurance Companies (2015) Official Gazette of the Republic of Serbia No. 51/2015; Decision on Bank's Risk Management (2015) Official Gazette of the Republic of Serbia No. RS 45/2011, 94/2011, 119/2012, 123/2012, 23/2013, 43/2013, 92/2013, 33/2015 and 61/2015
15 Site of NBS: http://www.nbs.rs/internet/cirilica/50/index.html, datum pristupa 17.04.2017

16 Site of NBS: http://www.nbs.rs/internet/cirilica/60/index.html, datum pristupa 17.04.2017

17 Site of NBS: http://www.nbs.rs/internet/cirilica/55/index.html; http://www.nbs.rs/ internet/ cirilica/60/index.html, date of access $04 / 17 / 2017$ 
The risk management regulation frame in the Republic of Serbia is the most developed in the banking sector, due to the fact that it started first in our country. Accordingly, banks are obliged to announce information on risk management in compliance with the third pillar of Basel II. ${ }^{18}$ However, it is important to emphasize that within the analyzed period five banks didn't publish the risk management practice on their sites - Raiffeisen, NLB, Sber, Halk and Piraeus. Furthermore, relevant data for those banks were collected from BRA's site - in the part Remarks to financial reports. ${ }^{19}$

A better quality of information in terms of the risk management practice (system, policy, rules, procedures, risk classification, risk management techniques in practice, methodology for calculating provisions, etc.) can be found on the sites of six banks: Intesa, Erste, UniCredit, Credit Agricole, NBG Vovjodjanska and ProCredit. A general conclusion is that the better quality of the risk management practice information is a result of the risk management development in the headquarters abroad, and of the competences of particular risk managers within the bank. The majority of banks announced bodies, acts and procedures relevant for risk management, models for provisions (for basic risks: credit, market and operational), by a method for a calculation of the risk exposure (Gap analysis, VaR, stress scenario, limit values of the basis points) and the risk mitigation techniques (models for credit risk estimation and hedging instruments for market risks). It can be concluded that: 1) banks have developed the risk management function on the basis of announced organizational charts; they reported the following risk management bodies: supervisory board, management board, credit committee, asset and liability committee and risk management functions (division, department or unit). 2) Reports on all risks which they are exposed to, with a specific accent on the capital requirements for the credit, market and operational risk. In accordance with: (I) Remarks to financial reports ${ }^{20}$, Raiffeisen bank reported that: 1) they had used the cash flow hedge since 2011, and the portfolio hedge since 2013 (thereby the hedge account methodology was explained);2) they used three derivates: foreign exchange (FX) forward, FX and interest rate swap. (II) The required risk management report ${ }^{21}$,EFG Eurobank published operational risk management practices and KPI (Key Performance Indicators).

The risk management in the insurance sector has been gradually developing and slowly follows trends in banking. It is commendable that NBS's site: 1) doesn't contain Excel tables with the basic performance indicators of insurance companies, i.e. it contains official financial reports and

18 Decision on Publishing Banks'Information and Data (2015) Official Gazette of Republic of Serbia No. 4/2015

19 Site of BRA's, http://www.apr.gov.rs/Регистри.aspx, date of access 04/19/2017.

20 Law on Auditing (2013) Official Gazette of the Republic of Serbia No. 62/2013

21 Decision on Publishing Banks'Information and Data (2015) Official Gazette of Republic of Serbia No. 4/2015 auditor opinion on it (in 2014 only four insurance companies had published all the relevant data for risk management). 2) Contains information about certified actuaries; 3) contains info about penalties to insurance companies i.e. responsible persons. It is important to stress that there is no information about 4 insurance companies on the site of NBS and BRA - Uniqa non-life, AXA life, Wiener Staditsche and Triglav osiguranje. A better quality on the risk management practice (system, policy, rules, procedures, risk classification, risk mitigation techniques, MCR - Minimal Capital Requirement, SCR - Solvency Capital Requirement, etc.) can be found on sites of 7 insurance companies: Generali, Grawe, AXA life, Dunav, Merkur, Societe Generale and Energoprojekt Garant (where the first three are significantly better compared to others). (I)Generali reported that: 1) they implemented Solvency II after the group did it. 2) They established Risk Management Division and Committee; 3) they used the risk management group methodology; 4) they implemented group recommendations for the asset and liability management (Generali CEE Holding); 5) the risk management practice was adjusted to achieve an adequate revenue (the relevant revenue rates are based on Generali CEE Holding Prague estimations). (II) Grawe emphasized that: 1) they had a risk management committee which included: a technical analyst, compliance manager, internal auditor, actuarial, asset and liability management officer, FATCA responsible officer and officer in charge of reporting according to Solvency 2. 2) They used an automated risk management process - Crystal Ball, 3) they invested in additional risk management trainings of relevant staff. (III) AXA life reported that following persons are responsible for risk management: 1) employees in the technical department for risk underwriting, 2) employees in the financial control for risk estimation, 3) management in accordance with its responsibilities.

Insurance companies stressed that they used the following methods to determine risk exposure: Liability Asset Test (LAT), VaR, sensitivity analysis, Chain Ladder Method, Loss Ratio method, CARMEL indicators, criteria for determination of the creditworthiness of the issuer of financial instrument, and management of the non-performing receivables. Some of the applied techniques for the risk mitigation are: financial derivates, protection of the data loss and non-authorized access, measures for recovery and business continuity, as well as diversification. Some of the insurance companies reported on the following categories: 1) risks - map of risks, risk importance, risk estimation, 2) indicators for risk exposure measuring: a percentage of settled claims, number of legal disputes with policyholders and customer satisfaction; 3) effectiveness indicators are average operations, assets derivates, financial information, operational mistakes and compliances with regulation. It can be concluded that: 1) Legislator prescribes in detail the risk management practice in this industry. Four main risk management functions 
in insurance companies are: risk management, internal control system, internal audit and actuarial. An own risk and solvency assessment (ORSA) and supervision based on the risk management are crucial for insurance companies. 2) Insurance companies paid attention to the quantitative risk management indicators (defined by the Law) and its fluctuations during the time (such as: a solvency margin, guarantee reserves, asset quality, technical result). 3) Insurance companies mainly reported on two basic risks: insurance and financial risks. 4) Insurance companies showed main actuarial opinion, internal audit's report summary and findings of external audit ${ }^{22}$ (supervisor - National bank of Serbia) if it was made within the current year.

Risk management in the real sector is at the early stage of development, according to the publicly announced data. Currently, all analysed companies are mainly reporting on risks prescribed by the International Standard of Financial Reporting 7 (IFRS). ${ }^{23}$ The risk management practice variety is derived from different ownership (domestic or foreign), i.e. in terms of the same ownership they belong to the same group of connected companies in the country or abroad. Furthermore, in case of domestic companies, there is a difference between privately and state owned companies. In accordance with it, the state owned legal entities have diametrically opposed practice in reporting business performance and risk management practice: 1 ) a good quality of risk management reporting such SMATSA (Serbia and Montenegro Air-Traffic Services SMATSA) and PE Post of Serbia /PTT/ (which expanded a list of risks with others relevant for their business, such as: a country risk, risk of deviation from the planned operating income, risk of deviation from the planned operating expenses); 2) do not publicly announce financial reports and risk management practice either on their site or BRA's site, such as the Serbian Railways JSC and the Building Directorate of Serbia.

In addition, companies in foreign-ownership and part of a group of connected companies, such as Philip Morris and Lafarge, applied the group risk management practices (primarily in terms of financial derivates). Then, companies in domestic ownership and part of a group of connected companies, reported in the same way on all risks (use the same wording for risk management and responsibilities, the only differences are in cash values which represent particular risk exposure), whereby they stressed that the owners were responsible for the capital risk management. Besides, there are companies which respect its industry specific and identified other related risks such as: 1) organizing games of chance - Mozzart, identified: a) other responsible persons for risk management, such as representatives of the human resource department; b) other risks, such as: market risks in terms of oscillations in the number of players, retention of quality staff, high dependence on the information technology, legal risk in terms of potentially risky contracts, and operational risk; 2) oil and petroleum products trade - NIS a.d. Novi Sad, expanded the list of market risk on price list of oil and petroleum products, and stressed the importance of the country risk based on sanctions on Russian's company business and Gazpromneft group. 3) Construction business - Energoprojekt, where operational risk is highlighted the first, but they didn't report on it. It is interesting that there are domestically owned companies (in domestic and foreign ownership) which have the risk management function according to the publicly announced information on different competent conferences (such as VIP, Atlantic group, Telenor, Viktorija group, Henkel, etc.), but they didn't report on it in their official financial reports.

An important conclusion is that on the basis of the publicly announced financial reports for insurance companies and companies in the real sector the decision about the quality of the risk management practice can't be made clear, i.e. if it has any connection with official financial indicators of each company such as a collection management, profit, provisions, reserves, income, etc., prepared in accordance with the international financial accounting and reporting standards.

Analyses showed that three legal entities developed their own risk classification, having in mind current regulation - Telenor bank, Grawe insurance and PE Post of Serbia. Accordingly: 1) Telenor bank classified risks on financial (credit, asset and liability management, FX, interest rate, liquidity risk) and non-financial risks (operational, information technologies/information systems, fraud, and cyber). 2) Grawe insurance had the following risk categories: internal surroundings / insurance technique, external surroundings / global risks, strategy, operational risks and equity investment. It is interesting that almost all insurance companies distinguished risks on insurance and financial risks, and reported on it (for example, Dunav insurance company did not report on the insurance risks). However, Generali insurance company introduced the third category of risk - operational risks. 3) PE Post of Serbia (PTT) expanded a list of risks with others relevant for their business, such as: a country risk, risk of deviation from the planned operating income, risk of deviation from planned operating expenses.

On the basis of everything presented in this chapter, it can be concluded that the main hypothesis of the research is proved. Furthermore, a relevant finding is that there is a different level of development of the risk management practice and reporting in different industry sectors.

22 Law on Auditing (2013) Official Gazette of the Republic of Serbia No. 62/2013.

23 International Financial Reporting Standards (IFRS), http://www. mfin.gov.rs/pages/article.php?id=10266 
Table 2. Basic risks in business of analysed companies

\begin{tabular}{|c|c|c|c|}
\hline Banks & Insurance companies & Real sector & Comment \\
\hline Credit risk & Insurance risk & Credit risk & $\begin{array}{l}\text { Exceptionally, some financial institutions show risks: credit- } \\
\text { FX, and credit-liquidity. }\end{array}$ \\
\hline Market risk & Market risk & Market risk & $\begin{array}{l}\text { Market risk mainly includes information about: FX risk, inter- } \\
\text { est rate risk, and price risk of the product subject of trade. The } \\
\text { industry which a company performs business in has an impact } \\
\text { on the importance of various market risks - for example insur- } \\
\text { ance companies stressed the importance of competition and } \\
\text { ability to adapt to the requirements of the insured. }\end{array}$ \\
\hline Liquidity risk & Operational risk & Liquidity risk & $\begin{array}{l}\text { Other risks for some insurance companies are strategical and } \\
\text { reputational risk. Some insurance companies reported sepa- } \\
\text { rately about a risk regarding informational technology. }\end{array}$ \\
\hline Exposure risks & $\begin{array}{l}\text { The risk of maturity } \\
\text { and structural mis- } \\
\text { match between assets } \\
\text { and liabilities }\end{array}$ & $\begin{array}{l}\text { Capital risk } \\
\text { management }\end{array}$ & $\begin{array}{l}\text { Some financial institutions report on the capital risk manage- } \\
\text { ment. }\end{array}$ \\
\hline Investment risk & $\begin{array}{l}\text { The risk of depositing } \\
\text { and investing assets of } \\
\text { the company }\end{array}$ & \multirow{5}{*}{ Tax risk } & \multirow[t]{2}{*}{$\begin{array}{l}\text { Tax risk includes: frequent changes in regulation, different } \\
\text { interpretation of tax regulations, and transfer prices opinion. } \\
\text { Some insurance companies reported on tax risk. }\end{array}$} \\
\hline Country risk & Legal risk & & \\
\hline Operational risk & Reputational risk & & NBG Vojvodjanska bank reported on three subcategories of \\
\hline Legal risk & \multirow[b]{2}{*}{ Other risks } & & the country risk: sovereignty, transfer and competition. \\
\hline $\begin{array}{l}\text { Reputational } \\
\text { risk }\end{array}$ & & & $\begin{array}{l}\text { Some banks reported about additional risks: a risk of intro- } \\
\text { ducing new products, risk of external and macroeconomic } \\
\text { surrounding, risks caused by the activities entrusted to other } \\
\text { parties. }\end{array}$ \\
\hline
\end{tabular}

Source: authors prepared this on the basis of available data on the site of NBS, BRA and Ministry of Finance of the Republic of Serbia

\section{CONCLUSION}

The enterprise risk management in Serbian companies is under a constant development. Varieties in the level of development of the risk management practice and reporting are determined by a regulation in the particular industry sector; different education, competence and experience of staff; ownership structure and applied information technologies. Furthermore, it is important to stress that there is a difference in the risk management development - practice and reporting within the same industries. An important conclusion is that the risk management practice and reporting is the area which needs permanent education of employees, investment in new technologies, and improvement of the essential and formal corporate governance process within the company. Future researches will go in the direction of ascertaining the connection between the risk management reporting and business performance of entities in the real and insurance sector.
This research paper was a part of the project "Advancing Serbia's Competitiveness in the Process of EU Accession", no. 47028, in the period 2011-2017, financed by the Serbian Ministry of Science and Technological Development.

\section{LITERATURE}

Barjaktarović, L., Pindžo, R., Đulić K., Vjetrov, A. (2017) Analiza primene ERM koncepta u Srbiji: uporedna analiza finansijskog i realnog sektora, Bankarstvo - at the publication stage

Barjaktarović L. (2013) Upravljanje rizikom, Univerzitet Singidunum, Beograd.

Barjaktarović, L., Vićentijević, K., Vjetrov, A. (2014) Analiza upravljanja rizicima na primeru kompanije Henkel, zbornik radova FINIZ 2014- Finansijsko izveštavanje u funkciji korporativnog upravljanja, str. 13-15.

Beasley M, Pagach D, Warr R. (2008) Information conveyed in hiring announcements of senior execuitvevs overseeing enterprise - wide risk management processes, Journal of Acounting, Auditing and Finance, pp. 23: 311-332. 
Business Info Group (2016) 100 najvećih 100 najboljih.

COSO (2004) Enterprise Risk management - Integrated Framework [http://www.coso.org/documents/COSO_ERM_ExecutiveSummary.pdf], date of access 05/25/2017.

Decision on Bank's Risk Management (2015) Official Gazette of the Republic of Serbia No. RS 45/2011, 94/2011, 119/2012, 123/2012, 23/2013, 43/2013, 92/2013, 33/2015 and 61/2015.

Decision on Management System in Insurance and Reinsurance Companies (2015) Official Gazette of the Republic of Serbia No. 51/2015.

Decision on Publishing Banks'Information and Data (2015) Official Gazette of the Republic of Serbia No. 4/2015.

International Financial Reporting Standards (IFRS), http://www. mfin.gov.rs/pages/article.php?id=10266 (relevant for Research ISFR 7), date of access 05/25/2017.

Jelenković, Z., Barjaktarović. (2016) The Risk Management Functions in the Conditions of Globalization: Case Study of the Republic of Serbia. Management 2016/79, pp. 37-45.

Law on Accounting (2013) Official Gazette of the Republic of Serbia No. 62/2013.

Law on Auditing (2013) Official Gazette of the Republic of Serbia No. $62 / 2013$.
Law on Banks (2015) Official Gazette of the Republic of Serbia No. 107/2005, 91/2010, 14/2015.

Law on Insurance (2014) Official Gazette of the Republic of Serbia No. 55/2004, 70/2004, 61/2005,85/2005, 101/2007, 63/2009, $107 / 2009,99 / 2011,119 / 2012,116 / 2013$ and 139/2014.

Law on Legal Entities (2015) Official Gazette of the Republic of Serbia No. 36/2011, 99/2011, 83/2014 - other laws and $5 / 2015$.

Law on National Bank of Serbia (2015) RS 72/2003, 55/2004, $85 / 2005,44 / 2010,76 / 2012,106 / 2012,14 / 2015,40 / 2015$.

Radoš, B. (2016) Upravljanje rizicima - trendovi i prakse. Zbornik radova FINIZ 2016 - Rizici u savremenim uslovima poslovanja. str. 82-87.

Site of BRA's, http://www.apr.gov.rs/Регистри.aspx, date of access 04/19/2017.

Site of NBS: http://www.nbs.rs/internet/cirilica/50/index.html, date of access 04/17/2017.

Site of NBS: http://www.nbs.rs/internet/cirilica/55/index.html, date of access 04/17/2017.

Site of NBS: http://www.nbs.rs/internet/cirilica/60/index.html, date of access 04/17/2017.

Vaughan, E., Vaughan, T. (1995) Osnovi osiguranja - Upravljanje rizicima, MATE (JohnWiley\&Sons, Inc.), Zagreb, 1995. 